IMPACT OF SOCIAL WORK PODCASTING

\title{
A Report on the Use of Open Access Podcasting in the Promotion of Social Work
}

\section{$\underline{\text { Published in }}$}

Fronek, P., Boddy, J., Chenoweth, L., \& Clark, J. (2016). A report on the use of open access podcasting in the promotion of social work. Australian Social Work, 69(1), 105-

114. doi:10.1080/0312407X.2014.991338

\begin{abstract}
Podcasting is the dissemination of asynchronous, downloadable digital media files. Amateur and professional podcasting have gained considerable popularity since the early 2000s. It is used as an alternate and flexible means of delivering course materials in higher education. Open access podcasting or podcasts available freely on the internet on specific disciplinary topics are gaining prominence but are not well researched. The paper explores the usefulness of a new podcast series for social workers freely available on the internet that aims to: promote the profession of social work and contribute to a social work identity; make connections between theory, research and practice; introduce students to real-life practice issues much earlier than often occurs in undergraduate degrees; and to provide practitioners with opportunities for ongoing professional development. Evaluation provides limited evidence that these aims are being met and concludes that further research is needed.
\end{abstract}

Key words: podcast, open access, social work education, on-line, social work 
IMPACT OF SOCIAL WORK PODCASTING

Podcasting has gained popularity in higher education since its widespread adoption by professional media and amateurs in particular fields of interest from the early 2000s. The media, early adopters of podcasting, offer radio shows via downloadable podcasts in areas such as health and science. Although podcasting appears in the academic literature as a method of presenting asynchronous on-line lecture material in higher education (Abdous, Facer \& Yen, 2012; Bolliger, Supanakorn, \& Boggs, 2010; Cartney, 2013; Harris, 2008; Heilesen, 2010; Hew, 2009; O’Bannon, 2011; Shantikumar, 2009), there is little that addresses the utility of open access podcasting as a tool to further disciplinary knowledge beyond a narrowly defined target audience such as students, and to cross geographical and discipline specific boundaries with the exception of some early papers on podcasting in astronomy and health (Gay, Price \& Searle, 2006; Jham, Duraes, Strassler \& Sensi, 2008; Price, Gay, Searle, Brissenden, 2006; Savel, Goldstein, Perencevich \& Angood, 2007).

The focus of academic inquiry is still primarily on podcasting as a new way of providing traditional education or in Massive Open Online Courses (MOOCs). Little is known about discipline-specific podcasting that aims to meet the multiple and varied needs of students, practitioners and researchers. The paper explores the usefulness, benefits and barriers of open access podcasting using a case example of a social work podcast series. A clear distinction is made between podcasts that are freely available to anyone with access to the internet, not provided by a university platform and not a formal component of assessable course material, and those podcasts hosted on a university platform or designed specifically as a formal component of a particular course or subject. 
IMPACT OF SOCIAL WORK PODCASTING

\section{The Literature}

A podcast is an asynchronous downloadable digital media file and RSS feed that can be audio, video or text (M4A, MP3, MOV, MP4, M4V and PDF) and is downloadable via webpages or digital media player applications such as iTunes. It does not refer to all kinds of media (flash animation, WMV files, streaming or digital media without RSS feeds) playable on mobile devices or the Internet (Blok \& Gondsk, 2009, p.118).

Advancements in portable audio and internet technologies facilitated the proliferation of podcasting by the mid 2000s. The Pew Research Internet Project reported that in 2004 fewer than 1,000 podcasts were listed by Podcast Alley, a podcast directory website, and by 2006 there were more than 26,000 podcasts (over one million episodes) (Madden, 2006). Podcast listeners are reported to like the capacity to control when and where to listen and the freedom to do other things while listening. The lure to podcasters keen to disseminate knowledge and ideas is the ease of self-publishing that presents economical and innovative uses of resources for universities and marketing opportunities for organisations (Blok \& Godsk, 2009).

Almost exclusively the academic literature addresses the utility of podcasting in education focusing on formal content within specific courses and programs either as a method of presenting lectures, revision of course material or as supplementary material (Evans, 2008; Heilesen, 2010). Abdous et al. (2012) pointed out that instructional podcasting is now considered commonplace in most universities as a method of engaging students and improving performance. Abdous et al. (2012) reviewed the literature on podcasting in higher education and reported mixed findings concerning the benefits of 
IMPACT OF SOCIAL WORK PODCASTING

podcasting. They concluded that support existed for podcasting as a tool for course material revision and enhancing students’ motivation but that research linking podcasting to improved performance shows varying results ranging from helpful or neutral to negatively impacting on attendance and active learning (Traphagan, Kucsera \& Kishi, 2010). Their own comparative study of integrated and supplementary uses of podcasts in second language classes supported the findings in the literature.

Others claim overall learning is enhanced by the emotional connections students make when they hear their instructor's voice (Popova \& Edirisingha, 2010). For instructors, podcasting some material saves time and creates opportunities for developing more creative in-class learning activities. Blok and Gondst (2009) found in their survey of 35,000 students and 8,500 academic staff that there were marked differences in how students and educators used podcasting with the majority of student use related to entertainment. They recommended the use of short and engaging podcasts rather than traditional uses of podcasting. When recordings were strictly related to course content, they reported that students tended to use computers rather than mobile devices whereas the reverse applied when listening for entertainment (Copely, 2007; Edirisingha, 2006; Hew, 2009).

\section{Open Access Social Work Podcasting}

Social work podcasting has a short history. Jonathan Singer, the creator and producer of the podcast series, The Social Work Podcast (http://socialworkpodcast.blogspot.com.au/), pioneered open access social work podcasting in the U.S. realizing the early benefits of complementing formal social work education with podcasts featuring guests on related topics (Singer, 2011). More social 
IMPACT OF SOCIAL WORK PODCASTING

work podcasts have since become available, some produced for specific purposes within defined temporal limits as well as in ongoing series formats for social workers, students and researchers.

The case example used in this paper to examine open access social work podcasting and its relevance to students, educators and practitioners is an Australian initiative. Beginning with an idea in 2010, Podsocs (http://www.podsocs.com/) “the podcast for social workers on the run”, was made possible by a Griffith University Learning and Teaching Grant and the first podcast was released on the $28^{\text {th }}$ July 2012. The initiative was ambitious drawing on a number of issues faced by contemporary social work such as the increasing criticism and blame that social work is often subjected to in the media and in politics. A crucial motivation for the Podsocs team is a commitment to the value of social work and the importance of a strong and unified sense of professional identity, for example, challenging perceptions that there is a division between practitioners and researchers.

The series was developed with four aims in mind: 1) to promote the profession of social work and contribute to a strong social work identity; 2) to make connections between theory, research and practice (by interviewing theorists, practitioners and researchers about their work); 3) to introduce students to real-life practice issues much earlier than often occurs in undergraduate degrees; and 4) to provide practitioners with opportunities for ongoing professional development. Each podcast is about thirty minutes in duration and intentionally features a broad range of topics from researchers, practitioners and service users or clients. The broadcasts are casual and conversational in delivery. In the first year podcasts were made available every week. They are now 
IMPACT OF SOCIAL WORK PODCASTING

released more or less monthly due to intensity of time required to produce each podcast. Interviews are conducted at any hour during a twenty-four hour period as appointments are made at the convenience of international and national guests. All recruitment of speakers, interviews, editing and publishing is done by the Podsocs team. A Facebook site, Twitter, and Pinterest are maintained featuring news about the podcasts and other items of interest to social workers. The team has no broadcasting or technical experience and skills have been acquired along the way. The unanticipated popularity of Podsocs has meant increased web hosting costs associated with maintaining the podcast that is paid for by the School of Human Services and Social Work. Otherwise, Podsocs has no ongoing funding.

\section{Method}

Three data sources were used to evaluate Podsocs - social media and website statistics, a survey of educators and students, and a content analysis of listener feedback. The student and educator survey, funded by the Learning and Teaching grant, was conducted during the first six months of Podsocs’ operation to meet the terms of the grant. The survey aimed to understand how students and educators were using Podsocs and how relevant the podcasts were to them. Social work educators and students studying social work, human services, or child and family were surveyed to determine the series’ integration into class material and how useful students found the podcasts in relation to aims 1-3. First and fourth-year students were asked to complete a thirteen point Likert scale questionnaire adapted from the scale used by Price et al.’s (2006) impact assessment of their astronomy podcast. The survey questions were related to the podcast’s aims. For 
IMPACT OF SOCIAL WORK PODCASTING

example, as shown in Table 1, Question 5 asked students if the podcasts make them feel excited about their future profession (aim 1), Question 10 asked students if the podcasts help them understand how what they learn at university is linked to practice (aim 2), and Question 3 asked students if the podcasts make social work/ human services work more real to them (aim 3). One class, in which all first-year students were enrolled, and another, in which all fourth-year students (social work only) were enrolled, were asked by their lecturers to complete the survey in class if they had listened to Podsocs. This approach was chosen to explore any differences in the experiences of students commencing their studies compared to those students near completion.

Qualitative feedback was expected to provide different information concerning the impact of the podcast series and provide information related to the fourth aim, providing practitioners with professional development opportunities. Two calls were distributed via Facebook and Twitter calling for listener feedback as there was no built-in survey capacity on the site. No feedback was received directly as a result of these requests. However, unsolicited feedback has been consistently received via email, Twitter and Facebook since the start of the series in 2012 plus requests for broadcasts on specific topics. In most cases, listeners who provided unsolicited feedback identified as educators, students or practitioners. A content analysis was conducted on the qualitative comments received since July 2012 to December 2013 and the qualitative feedback provided in the student survey. A number of one-liner 'thank yous” have been received and were not included in the analysis.

\section{Findings}


IMPACT OF SOCIAL WORK PODCASTING

In 2012, six months after the first podcast was published online, Podsocs had 296 Facebook likes and 256 followers on Twitter. Twelve months later, Podsocs had 850 followers on Twitter and 509 Facebook likes indicating organic growth over time. There have been 17,000 podcast downloads from the website since the Podsocs startup and visitors from sixty countries. It has not been possible to collect statistics on iTunes downloads.

Two thirds of the nine educators that responded to the survey had integrated relevant podcasts into course resources. Twenty-two students (thirteen first-year, nine fourth-year) completed the survey. Due to the small numbers surveyed, limited conclusions can be drawn from statistical analysis. Results are therefore descriptive and evaluative (see Table 1).

Overall, responses from the total student group were positive. All students understood the concepts presented in the podcasts, found them relevant to their studies and nine reported that they would keep listening after graduation. The majority of responses to other questions were mostly positive with some single responses that were either undecided, disagreed or tended to disagree. The most variation occurred in the following: four students did not listen a lot; three students did not like the choice of shows; and five students had not told anyone else about Podsocs. Interestingly there were some differences between first and final year students on comparison. Although fourthyear students found Podsocs more relevant to their studies, made them feel more excited about their future profession and prouder to be part of the university, it was first-year students who listened more. While acknowledging it is difficult to draw firm conclusions 
IMPACT OF SOCIAL WORK PODCASTING

from this - students' available time, desire for knowledge, relevance to assessable items or professional identity, or future work opportunities could be factors.

Qualitative feedback was overwhelmingly positive and tended to support Podsocs aims, particularly 1 and 4 . This is surprising as the public can also access the podcasts which include challenging and potentially controversial topics such as transsexualism and intercountry adoption. Perhaps it can be assumed if people did not like the podcasts, they simply did not listen or were able to pick and choose topics that appealed.

Comments from students and practitioners drew attention to the flexibility podcasting allowed. For example, one student said:

...The recordings allowed for me as a busy mum to listen and gather knowledge...[while] getting ready in the morning...I was never able to listen in one complete sitting over a couple of days I was able to complete a full recording... [I wrote] so that the creators... know the positive impact it has made... The site kept me informed, engaged and opened my mind up to so many ideas...this site is such a great tool.

Geographical barriers were also overcome. One student wrote from placement in Nepal: "...I had a light bulb moment the other day whilst listening to some Podsocs (which I LOVE by the way) on a bus trip between Kathmandu and Pokhara...Fantastic!"

Students generally reported the relevance of podcasts to assignments or their personal benefit and enjoyment. For example, one student reported "...I really enjoyed the podsocs they were great... I also enjoyed each topic for the weeks and how they fit so nicely with each assessment piece..." Another student emailed that she was "Just 
IMPACT OF SOCIAL WORK PODCASTING

finishing up listening to my first podcast - fantastic!! I am in danger of becoming antisocial as I am growing attached to my headphones!!"

Educators from countries such as Australia, the US, UK and India reported using the podcasts to complement course material and how useful students found the podcasts and made comments such as "...had a listen to the podsocs and thought they were good I thought you might want to know that I have added them to my students list of useful sites on Blackboard..." and "...Pod Socs is so innovative-all our students are aware of it and are loving it".

Qualitative comments received from practitioners indicated that the podcasts were relevant and were being used in professional development sessions. For example, "I plan on hosting a little 'lunch and learn' to introduce it [Podsocs] to some of my colleagues here...I've already gained something out of the podcast on 'resilience in supervision in social work’...". Another practitioner reported "Thank you for such wonderful podcasts! They are inspirational, informative and make me value my profession more every time! ".

No negative comments have been received. Instead, helpful support has been offered. For example, one practitioner with experience in community radio offered assistance on improving the sound of early recordings. Web statistics, internal evaluation and qualitative feedback from listeners suggest that Podsocs is generally well-received and is meeting some need in the global social work community.

\section{Discussion and Conclusion}

As previously stated, Podsocs was developed with four aims: to promote the profession of social work and contribute to a strong social work identity; make 
IMPACT OF SOCIAL WORK PODCASTING

connections between theory, research and practice; to introduce students to real-life practice issues much earlier than often occurs in undergraduate degrees; and to provide professional development opportunities for practitioners. We have provided limited evidence that these aims may be met via open access podcasting. It is difficult to draw generalized conclusions from the evaluation and ongoing feedback. However, given that social workers are listening to Podsocs, it seems that there is support for specific material with which social workers can identify. For example, a social worker or student may read an article relevant to their work or studies and then be able to listen to the author discuss their work in a casual, conversational way. Open access podcasting delivers social work topics in the space between academia and entertainment that is at the same time interesting and informative. There is a tension between delivering serious material in a way that is more akin to entertainment than formal higher education without trivializing the content. Social work has lagged behind other disciplines such as science that has used podcasting to inform a wider audience since the mid 2000s (Gay et al., 2006). Productions like Podsocs may help meet this gap.

Although, benefits for coursework material delivered via podcasting have been identified, Podsocs does not make any claims to substitute for formal higher education whether by traditional delivery or via MOOCS. Rather it provides complementary learning in a format new to the profession of social work that could be used creatively in student coursework and for professional development. The relationships between theory, practice and research is important in social work, yet it is sometimes difficult for students for make these connections. Podcasts provide opportunities to hear how, for example, research is conducted by practitioners and how knowledge is generated in practice 
IMPACT OF SOCIAL WORK PODCASTING

helping to close the gap between the two. Podcasting for practitioners seeking

professional development in overworked and budget-driven environments appears to be a useful resource due to its flexibility. It also seems reasonable to assume that podcasting is an appropriate vehicle for promoting broader social awareness and highlighting areas of disadvantage, discrimination and inequality as well as showcasing research and emerging issues. Each of these observations provide opportunities for further research, especially who listens to open access podcasts, how they listen and why, how educators integrate podcasts into their teaching and learning approaches, the implications for students learning, and to measure the impact of open access podcasting in social work.

Podsocs, not enhanced by professional broadcasting or technical expertise, has nonetheless been well and widely received. It is the strong grounding in the values of the profession - human rights and social justice - that we believe appeals to human services audiences and the general public.

There have been many barriers in the development and production of Podsocs in terms of technical knowledge, time and lack of financial backing that would enable Podsocs to be produced as part of teaching allocations rather than in one's own time, to make production improvements, and access technological support. For these reasons, it was two years before the first podcast was published. Choosing not to use a university platform has had both benefits (flexibility and accessibility) and drawbacks (ongoing costs).

There are a number of limitations to this evaluation and room for robust and longitudinal research that measures impact. Built in surveys on the website are desirable future 
IMPACT OF SOCIAL WORK PODCASTING

additions. The evaluation, however, does demonstrate international interest in social work podcasts.

In conclusion, podcasting presents a number of opportunities for the social work profession. It may provide an informal method of disseminating social work knowledge and build stronger relationships between theory, research and practice in the space between formal learning and entertainment. Access to professional development for practitioners is becoming increasingly difficult in contemporary organisations and podcasting can help fill this gap as it is low cost and is easily accessed. Social work's image is often subjected to derision in the press and the practice of social work can sometimes feel isolating. Podcasting provides a means of connecting with peers and can generate a sense of belonging and connection within a difficult profession. Social work is an important voice in pressing and emerging social issues such as increasing inequalities. Open access podcasting provides opportunities for social work to contribute in a meaningful way to public commentary and help shape a rapidly changing world. 
IMPACT OF SOCIAL WORK PODCASTING

\section{References}

Abdous, M., Facer, B. R., \& Yen, C.-J. (2012). Academic effectiveness of podcasting: A comparative study of integrated versus supplemental use of podcasting in second language classes. Computers \& Education, 58(1), 43-52.

doi:10.1016/j.compedu.2011.08.021.

Blok, R., \& Godsk, M. (2009). Podcasts in higher education: What students want, what they really need, and how this might be supported, World Conference on ELearning in Corporate, Government, Healthcare, and Higher Education 2009. Vancouver, Canada: AACE.

Bolliger, D. U., Supanakorn, S., \& Boggs, C. (2010). Impact of podcasting on student motivation in the online learning environment. Computers \& Education, 55(2), 714-722. doi: 10.1016/j.compedu.2010.03.004.

Cartney, P. (2013). Podcasting in an age of austerity: A way of both enhancing student learning and reducing staffing costs? British Journal of Social Work, 43(3), 446466. doi: 10.1093/bjsw/bcr187.

Copley, J. (2007). Audio and video podcasts of lectures for campus-based students: Production and evaluation of student use. Innovations in Education and Teaching International, 44(4), 387-399. doi:10.1080/14703290701602805.

Edirisingha, P. (2006). The "double life" of an i-Pod: A case study of the educational potential of new technologies, Online Educa 2006. Berlin: Beyond Distance Research Alliance, University of Leicester. Retrieved April 24, 2014 from http://www2.le.ac.uk/departments/beyond-distance-research- 
IMPACT OF SOCIAL WORK PODCASTING

alliance/disseminationactivities/conferences/2006/OnlineEduca2006/OnlineEduca 2006Presentations/double_ipod.

Evans, C. (2008). The effectiveness of m-learning in the form of podcast revision lectures in higher education. Computers \& Education, 50(2), 491-498. doi:10.1016/j.compedu.2007.09.016.

Gay, P. L., Price, A., \& Searle, T. (2006). Astronomy podcasting: A low-cost tool for affecting attitudes in diverse audiences. Astronomy Education Review, 5(1), 36-52.

Harris, H., \& Park, S. (2008). Educational usages of podcasting. British Journal of Educational Technology, 39(3), 548-551. doi:10.1111/j.1467-8535.2007.00788.x.

Heilesen, S. B. (2010). What is the academic efficacy of podcasting? Computers \& Education, 55(3), 1063-1068. doi:10.1016/j.compedu.2010.05.002.

Hew, K. (2009). Use of audio podcast in K-12 and higher education: A review of research topics and methodologies. Educational Technology Research and Development, 57(3), 333-357. doi:10.1007/s11423-008-9108-3.

Jham, B. C., Duraes, G. V., Strassler, H. E., \& Sensi, L. G. (2008). Joining the podcast revolution. Journal of Dental Education, 72(3), 278-281.

O'Bannon, B. W., Lubke, J. K., Beard, J. L., \& Britt, V. G. (2011). Using podcasts to replace lecture: Effects on student achievement. Computers \& Education, 57(3), 1885-1892. doi:10.1016/j.compedu.2011.04.001.

Madden, M. (2006). Podcast Downloading: Pew Research Internet Project. Retrieved April 24, 2014 from http://www.pewinternet.org/2006/11/22/podcastdownloading/. 
IMPACT OF SOCIAL WORK PODCASTING

Popova, A., \& Edirisingha, P. (2010). How can podcasts support engaging students in learning activities? Procedia - Social and Behavioral Sciences, 2(2), 5034-5038. doi.org/10.1016/j.sbspro.2010.03.816.

Price, A., Gay, P., Searle, T., \& Brissenden, G. (2006). A history and informal assessment of the Slacker Astronomy Podcast. Astronomy Education Review, 5(1), 53-69.

Savel, R. H., Goldstein, E. B., Perencevich, E. N., \& Angood, P. B. (2007). The iCritical Care Podcast: A novel medium for critical care communication and education. Journal of the American Medical Informatics Association, 14(1), 94-99. doi:10.1197/jamia.M2205.

Shantikumar, S. (2009). From lecture theatre to portable media: Students' perceptions of an enhanced podcast for revision. Medical Teacher, 31(6), 535-538. doi:10.1080/01421590802365584.

Smith, S. D., \& Caruso, J. B. (2010). The ECAR Study of Undergraduate Students and Information Technology, 2010: EDUCAUSE Centre for Applied Research.

Singer, J. B. (2011). Behind the scenes at the Social Work Podcast: Interview with Jonathon Singer [Episode 64]. Social Work Podcast. Podcast retrieved September 11, 2011 from http://socialworkpodcast.blogspot.com/2011/01/behind-scenes-atsocial-work-podcast.html.

Traphagan, T., Kucsera, J., \& Kishi, K. (2010). Impact of class lecture webcasting on attendance and learning. Educational Technology Research and Development, 58(1), 19-37. doi:10.1007/s11423-009-9128-7. 
IMPACT OF SOCIAL WORK PODCASTING

Walls, S. M., Kucsera, J. V., Walker, J. D., Acee, T. W., McVaugh, N. K., \& Robinson, D. H. (2010). Podcasting in education: Are students as ready and eager as we think they are? Computers \& Education, 54(2), 371-378. doi:10.1016/j.compedu.2009.08.018. 
IMPACT OF SOCIAL WORK PODCASTING

Table 1 Aggregate Numbers for Responses for Likert Scale for the Student Group \& Comparison of the First-Year and Fourth-Year Students

\begin{tabular}{|c|c|c|c|c|c|c|c|c|c|c|c|c|c|}
\hline & \multirow[t]{2}{*}{ 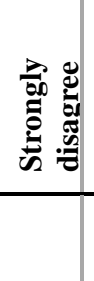 } & \multirow[t]{2}{*}{ 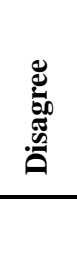 } & \multirow[t]{2}{*}{ 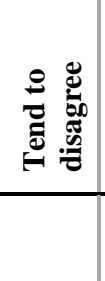 } & \multirow[t]{2}{*}{ خ } & \multirow[t]{2}{*}{ 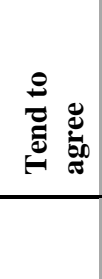 } & \multirow[t]{2}{*}{ 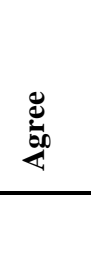 } & \multirow[t]{2}{*}{ 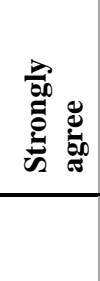 } & \multicolumn{2}{|c|}{ Median } & \multicolumn{2}{|c|}{ Range } & \multicolumn{2}{|c|}{$\begin{array}{l}\text { Inter- } \\
\text { quartile } \\
\text { range }\end{array}$} \\
\hline & & & & & & & & $\begin{array}{l}1^{\text {st }} \\
\text { YR }\end{array}$ & $\begin{array}{l}4^{\text {th }} \\
\text { YR }\end{array}$ & $\begin{array}{l}\text { st }^{\text {st }} \\
\text { YR }\end{array}$ & $\begin{array}{l}\text { st }^{\text {st }} \\
\text { YR }\end{array}$ & $\begin{array}{l}4^{\text {th }} \\
\text { YR }\end{array}$ & $\begin{array}{l}1^{\text {st }} \\
\text { YR }\end{array}$ \\
\hline $\begin{array}{l}\text { 1. I understand the } \\
\text { concepts in the } \\
\text { podcasts show }\end{array}$ & & & & & $\begin{array}{l}3 \\
13.6 \%\end{array}$ & $\begin{array}{l}13 \\
59.1 \%\end{array}$ & $\begin{array}{l}6 \\
27.3 \%\end{array}$ & 6 & 6 & 2 & 6 & 6 & 2 \\
\hline $\begin{array}{l}\text { 2. The podcasts are } \\
\text { relevant to my } \\
\text { studies }\end{array}$ & & & & & $\begin{array}{l}2 \\
9.1 \%\end{array}$ & $\begin{array}{l}11 \\
50 \%\end{array}$ & $\begin{array}{l}9 \\
40.9 \%\end{array}$ & 6 & 7 & 2 & 6 & 7 & 2 \\
\hline $\begin{array}{l}\text { 3. The podcasts } \\
\text { have helped me } \\
\text { understand my } \\
\text { course better }\end{array}$ & & $\begin{array}{l}1 \\
4.5 \%\end{array}$ & & & $\begin{array}{l}3 \\
13.6 \%\end{array}$ & $\begin{array}{l}11 \\
50 \%\end{array}$ & $\begin{array}{l}7 \\
31.8 \%\end{array}$ & 6 & 6 & 5 & 6 & 6 & 5 \\
\hline $\begin{array}{l}\text { 4. The podcasts } \\
\text { make social } \\
\text { work/human } \\
\text { services work more } \\
\text { real to me }\end{array}$ & & & $\begin{array}{l}1 \\
4.5 \%\end{array}$ & $\begin{array}{l}1 \\
4.5 \%\end{array}$ & & $\begin{array}{l}12 \\
54.5 \%\end{array}$ & $\begin{array}{l}8 \\
36.4 \%\end{array}$ & 6 & 6 & 4 & 6 & 6 & 4 \\
\hline $\begin{array}{l}\text { 5. The podcasts } \\
\text { make me feel } \\
\text { excited about my } \\
\text { future profession }\end{array}$ & $\begin{array}{l}1 \\
4.5 \%\end{array}$ & & & $\begin{array}{l}2 \\
9.1 \%\end{array}$ & $\begin{array}{l}3 \\
13.6 \%\end{array}$ & $\begin{array}{l}9 \\
40.9 \%\end{array}$ & $\begin{array}{l}7 \\
31.8 \%\end{array}$ & 6 & 7 & 6 & 6 & 7 & 6 \\
\hline $\begin{array}{l}\text { 6. I use the } \\
\text { podcasts to } \\
\text { complement my } \\
\text { studies }\end{array}$ & $\begin{array}{l}1 \\
4.5 \%\end{array}$ & & & $\begin{array}{l}2 \\
9.1 \%\end{array}$ & $\begin{array}{l}6 \\
27.3 \%\end{array}$ & $\begin{array}{l}11 \\
50 \%\end{array}$ & $\begin{array}{l}2 \\
9.1 \%\end{array}$ & 6 & 6 & 6 & 6 & 6 & 6 \\
\hline $\begin{array}{l}\text { 7. I enjoy listening } \\
\text { to the podcasts }\end{array}$ & $\begin{array}{l}1 \\
4.5 \%\end{array}$ & & & $\begin{array}{l}1 \\
4.5 \%\end{array}$ & $\begin{array}{l}2 \\
9.1 \%\end{array}$ & $\begin{array}{l}12 \\
54.5 \%\end{array}$ & $\begin{array}{l}6 \\
27.3\end{array}$ & 6 & 6 & 6 & 6 & 6 & 6 \\
\hline $\begin{array}{l}\text { 8. The podcasts } \\
\text { make me feel } \\
\text { proud of being part } \\
\text { of Griffith } \\
\text { University }\end{array}$ & $\begin{array}{l}1 \\
4.5 \%\end{array}$ & & & $\begin{array}{l}1 \\
4.5 \%\end{array}$ & $\begin{array}{l}8 \\
36.4 \%\end{array}$ & $\begin{array}{l}7 \\
31.8 \&\end{array}$ & $\begin{array}{l}5 \\
22.7 \%\end{array}$ & 5 & 6 & 6 & 5 & 6 & 6 \\
\hline $\begin{array}{l}\text { 9. I have told other } \\
\text { people about the } \\
\text { social work podcast }\end{array}$ & $\begin{array}{l}1 \\
4.8 \%\end{array}$ & $\begin{array}{l}1 \\
4.8 \%\end{array}$ & $\begin{array}{l}3 \\
14.3 \%\end{array}$ & $\begin{array}{l}5 \\
23.8 \%\end{array}$ & $\begin{array}{l}4 \\
19 \%\end{array}$ & $\begin{array}{l}5 \\
23.8 \%\end{array}$ & $\begin{array}{l}2 \\
9.5 \%\end{array}$ & 4 & 6 & 6 & 4 & 6 & 6 \\
\hline $\begin{array}{l}\text { 10. The podcasts } \\
\text { have helped me } \\
\text { understand how } \\
\text { what I learn at } \\
\text { university is linked } \\
\text { to practice }\end{array}$ & & & $\begin{array}{l}1 \\
4.5 \%\end{array}$ & & $\begin{array}{l}5 \\
22.7 \%\end{array}$ & $\begin{array}{l}10 \\
45.5 \%\end{array}$ & $\begin{array}{l}5 \\
22.7 \%\end{array}$ & 6 & 6 & 4 & 6 & 6 & 4 \\
\hline $\begin{array}{l}\text { 11. I listen to the } \\
\text { podcasts a lot }\end{array}$ & & $\begin{array}{l}1 \\
4.5 \%\end{array}$ & $\begin{array}{l}1 \\
4.5 \%\end{array}$ & $\begin{array}{l}4 \\
18.2 \%\end{array}$ & $\begin{array}{l}7 \\
31.8 \%\end{array}$ & $\begin{array}{l}8 \\
36.4 \%\end{array}$ & $\begin{array}{l}1 \\
4.5 \%\end{array}$ & 6 & 5 & 5 & 6 & 5 & 5 \\
\hline $\begin{array}{l}\text { 12. I like the choice } \\
\text { of shows }\end{array}$ & $\begin{array}{l}1 \\
4.5 \%\end{array}$ & $\begin{array}{l}1 \\
4.5 \%\end{array}$ & & $\begin{array}{l}3 \\
13.6 \%\end{array}$ & $\begin{array}{l}3 \\
13.6 \%\end{array}$ & $\begin{array}{l}12 \\
54.5 \%\end{array}$ & $\begin{array}{l}2 \\
9.1 \%\end{array}$ & 6 & 6 & 6 & 6 & 6 & 6 \\
\hline $\begin{array}{l}\text { 13. I think I will } \\
\text { keep listening to } \\
\text { the shows after I } \\
\text { graduate }\end{array}$ & & & & & $\begin{array}{l}2 \\
22.2 \%\end{array}$ & $\begin{array}{l}5 \\
55.6 \%\end{array}$ & $\begin{array}{l}2 \\
22.2 \%\end{array}$ & 5 & 6 & 2 & 5 & 6 & 2 \\
\hline
\end{tabular}

